\title{
A Two-stage Micropropagation System for Cranberries
}

\author{
Michael Marcotrigiano' and Susan P. McGlew ${ }^{2}$ \\ Department of Plant and Soil Sciences, University of Massachusetts, Amherst, MA 01003
}

Additional index words. Vaccinium macrocarpon, Ericaceae, tissue culture, shoot cultures, rooting, propagation, shoot proliferation

\begin{abstract}
A two-stage micropropagation system was devised for cranberries (Vaccinium macrocarpon Ait.). Shoottip explants taken from four cultivars of greenhouse-grown plants were placed on media composed of Anderson's major salts, Murashige and Skoog's (MS) minor salts and organics, plus various concentrations of 2iP, IBA, and GA $_{3}$. In other experiments, explant source, salt formulations for media, and rooting treatments were studied. Optimal multiplication and shoot quality occurred when nodal explants taken from greenhouse-grown or micropropagated plants were placed on medium containing $150 \mu \mathrm{M} 2 \mathrm{iP}, 1.0 \mu \mathrm{M}$ IBA, and no GA . Histological examination revealed that the initial response of nodes to culture is axillary bud proliferation, but adventitious shoot formation occurred after 4 to 6 weeks. Cultures that contained only axillary shoots were not evident unless low levels of $2 \mathrm{iP}$ were used, at which point only axillary buds present on the explants were released. Proliferated shoots could be rooted ex vitro without auxin treatment. Optimal rooting occurred under high-light conditions. Plants were transplanted to the field for comparison to conventionally propagated material. Chemical names used: gibberellic acid $\left(G^{-} A_{3}\right), N-(3-m e t h y l-2-$ butenyl)-1H-purin-6-amine (2iP), 1H-indole-3-butanoic acid (IBA).
\end{abstract}

The value of the U.S. cranberry crop has risen dramatically in the last few decades (Eck, 1990). In 1986, a record U.S. farm value of $\$ 190$ million was achieved when more than 166,000 $\mathrm{t}$ of fruit was produced. Cranberries are mainly grown in Massachusetts and Wisconsin on $\approx 4500$ and 3200 ha, respectively (Eck, 1990). Although cranberries area high-value crop, tissue culture technology lags far behind in comparison to other Vaccinium species. For example, procedures for micropropagation and/or adventitious shoot regeneration have been reported for highbush blueberries ( $V$. corymbosum) (Billings et al., 1988; Callow et al., 1989; Chandler and Draper, 1986; Wolfe et al., 1983), lowbush blueberries (V. angustifolium) (Frett and Smagula, 1983; Nickerson, 1978), and rabbiteye blueberry (V. ashei) (Lyrene, 1980).

Preliminary work on cranberry ( $V$. macrocarpon) tissue culture has been reported. Scorza et al. (1984) concluded that the herbicide glyphosate, alone or in combination with $2 \mathrm{iP}$, increases axillary shoot formation in cultured cranberry nodes. However, proliferation rates were fairly low (5 to 7 times), and the ability to subculture or root the shoots was not reported. Most recently, Serres et al. (1990) presented data that suggest the stable expression of a foreign gene, introduced into cultured cranberry stems via particle acceleration technology.

Cranberries are commercially propagated by pressing stem cuttings into freshly sanded bogs where they readily form adventitious roots and later spread by producing horizontal shoots. The ease with which cuttings root may not warrant the development of micropropagation procedures to clone existing cultivars. However, micropropagation technology can aid in cranberry improvement because it would allow for the rapid increase of desirable bud sports, seedlings derived from breeding programs, or genetically engineered plants. If virus-indexed

\footnotetext{
Received for publication 4 Sept. 1990. Publication no. 3016 of the Massachusetts Agricultural Experiment Station. This research was supported in part by financial assistance and equipment donations from Ocean Spray Cranberries, Inc. We are grateful for the cooperation of Jack Crooks. The cost of publishing this paper was defrayed in part by the payment of page charges. Under postal regulations, this paper therefore must be hereby marked advertisement solely to indicate this fact.

${ }^{1}$ Associate Professor.

${ }^{2}$ Research Technician.
}

stock cultures can be obtained, bogs could be established from pathogen-tested material. To our knowledge, there have been no reports on the growth of cranberries established from tissuecultured material and, therefore, there have been no evaluations of the phenotypic or genetic stability of micropropagated shoots. If a tissue culture system results in variability, it maybe possible to use such a system to augment a breeding program. In addition, since branching patterns in micropropagated small fruit species frequently differ from conventionally propagated material (Marcotrigiano et al., 1984; Read et al., 1987), the architecture of a bog may be modified when it is initiated with micropropagated plants, with possible benefits to the mechanical harvesting procedure. It is for the above reasons that we have initiated research on the development of a micropropagation system in cranberry.

In this report, we define a simple two-stage micropropagation system for high- frequency shoot proliferation and rooting of cranberry plants that were derived from shoot tips or nodes. We have combined Stage I and Stage II (the establishment and multiplication stages) and eliminated Stage III (the pretransplant stage) described by Murashige (1974).

\section{Materials and Methods}

General methods. Unless otherwise noted, explants consisted of terminal vegetative shoot tips (10-15 mm long) taken from greenhouse-grown plants. For surface sterilization, shoot tips were swirled in soapy tap water for 10 min followed by several tap water rinses. Explants were then swirled for $10 \mathrm{~min}$ in $0.5 \%$ sodium hypochlonte (10\% Clorox) containing 10 drops of Tween 20/liter and then rinsed three times in sterile distilled water. For all experiments, cultures were grown using one explant per 25 $\times 95-\mathrm{mm}$ glass vial, each of which contained $10 \mathrm{ml}$ of medium solidified on a slant and was capped with clear permeable membrane caps (Biomedical Polymers, Leominster, Mass.). The addition of all ingredients and $\mathrm{pH}$ adjustment were done before autoclaving. Media were adjusted to $\mathrm{pH} 4.5$ and Difco Bacto agar (8 g.liter ${ }^{-1}$, was added. In some experiments, media salt formulations were tested. In all cases, however, the organic components of the basal media (i.e., vitamins, etc.) were that of Murashige and Skoog (1962). Cultures were grown at 25C in lighted incubators with a 16-h photoperiod using cool-white 
fluorescent lamps $\left(36 \pm 9 \mu \mathrm{mol} \cdot \mathrm{s}^{-1} \cdot \mathrm{m}^{-2}\right)$. When shoot-tip explants were used, the original shoot was included in the shoot proliferation data. Subculturing consisted of randomly selecting a single shoot from each vial and transferring the appropriate explant from that shoot to fresh medium.

Shoot multiplication (Expt. 1). The purpose of this experiment was to determine how growth regulator concentration and type effect shoot proliferation of four cranberry cultivars. We used a $2 \times 2 \times 3 \times 4 \times 3$ factorial experimental design (completely randomized) to study all possible combinations of 0 and $5 \mu \mathrm{M} \mathrm{GA}_{3}, 0$ and $1 \mu \mathrm{M} \mathrm{IBA}$, and 0,150 , and $300 \mu \mathrm{M}$ $2 \mathrm{iP}$ and the four cultivars Beckwith, Bergman, Franklin, and Stevens over three culture periods (initial culture and two subcultures). Shoots were subculture at 10-week intervals. There were 10 single-vial replicates per treatment. Anderson's major salts (Anderson, 1975) and MS minor salts (Murashige and Skoog, 1962) were used. Because the effects of serial subculturing were studied, nondestructive observations were made of shoot count, color, and the presence of a basal clump of dense meristematic callus. We estimate a maximum error of $10 \%$ in observations of shoot count on cultures that were highly responsive.

Evaluation of cytokinin levels (Expt. 2). In Expt. 1, some of the shoots produced at the lowest tested level of $2 \mathrm{iP}$ were apparently adventitious (Fig. 1). This experiment was initiated to determine the influence of $2 \mathrm{iP}$ levels from 0 to $150 \mu \mathrm{M}$ on the production of axillary and adventitious shoots. All media contained $1 \mu \mathrm{M}$ IBA, and the $2 \mathrm{iP}$ levels tested were $0,5,25,50$, and $150 \mu \mathrm{M}$. All procedures were as in Expt. 1, except that two-node explants were used. Data were collected after 7 weeks. Shoots were considered axillary if they arose directly from a node. Shoots arising from unique sites of the basal meristematic callus were considered adventitious. Some of these shoots may have been axillary shoots arising from within the meristematic mass, but this could not be determined without histological preparation. Our data, therefore, may have inflated the number of adventitious shoots.

Inorganic nutrition for shoot cultures (Expt. 3). To evaluate the potential use of commercially available major and minor salt formulations and the effects of mineral composition on shoot proliferation and shoot quality, media composed of the major and minor salt formulations B-5 (Gamborg et al., 1968), Woody Plant Medium (WPM) (Lloyd and McCown, 1980), MS (Murashige and Skoog, 1962), and Anderson's (Anderson, 1975) (all from Sigma Chemical, St. Louis) were tested. Before autoclaving, $150 \mu \mathrm{M} 2 \mathrm{iP}$ and $1 \mu \mathrm{M}$ IBA was added. There were eight replications for each cultivar. Shoot height and count were recorded after an initial 12 weeks of culture. Shoot tips were subculture twice at 8-week intervals, with data taken at each subculture.

Explant source (Expt. 4). To determine if nodal stem sections were more responsive than cultured shoot tips, a $2 \times 2 \times 2$ factorial experiment (completely randomized) was initiated comparing node vs. tip sections, explants removed from proliferating shoot cultures vs. greenhouse-grown plants, and two cultivars ('Bergman' or 'Franklin'). The medium consisted of Anderson's major salts (Anderson, 1975), MS minor salts and organics (Murashige and Skoog, 1962), plus $150 \mu \mathrm{M} 2 \mathrm{iP}$ and 1 PM IBA. Explants were 15-mm shoot tips or nodal stem sections (possessing two nodes, leaves intact) taken from 16-week-old shoot cultures or actively growing greenhouse-grown plants. The two-node explants were taken from regions of the stem that contained fully expanded mature leaves. Shoot tip explants were inserted halfway into the medium, and nodal explants were placed
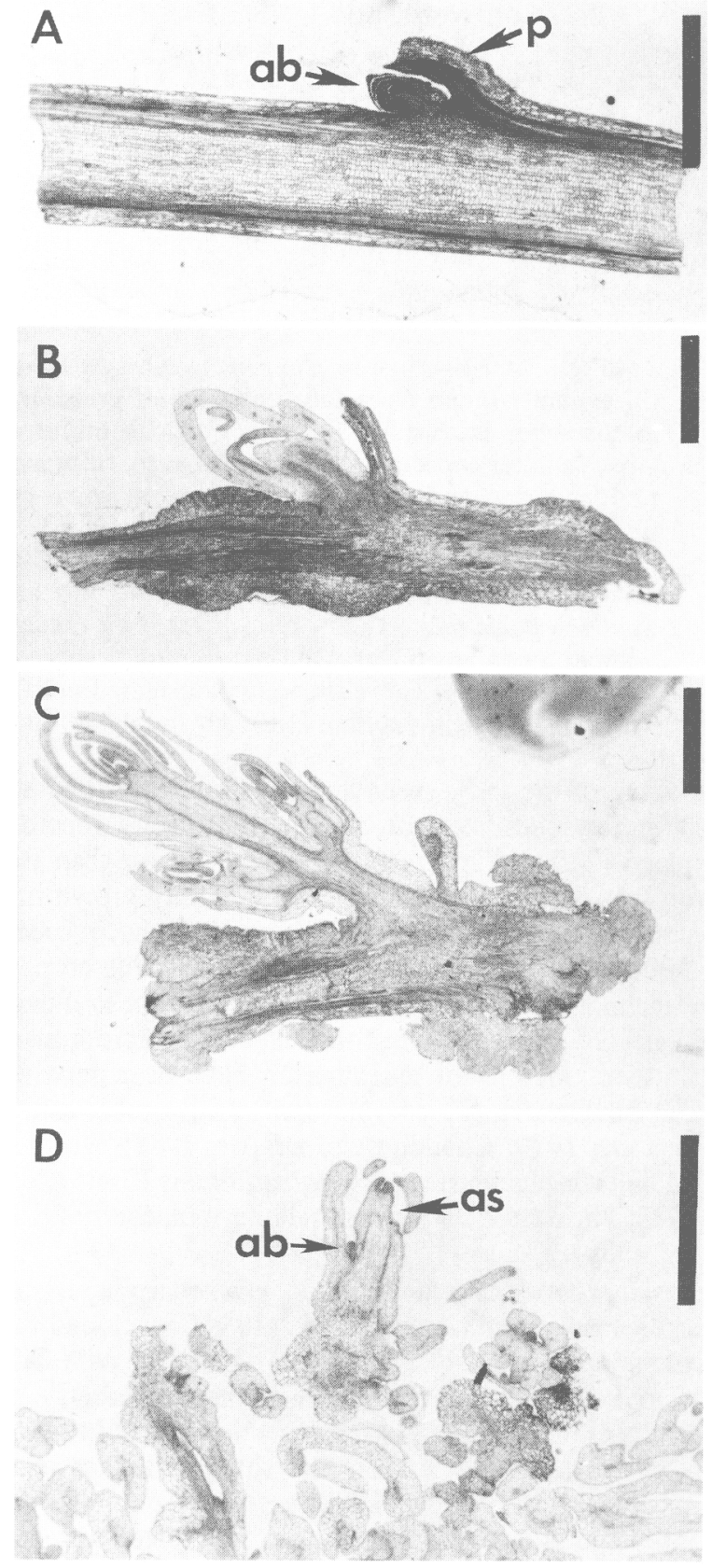

Fig. 1. Median or near median longitudinal sections of cranberry nodal explants and cultures. (A) Explanted single node before culture; $\mathrm{ab}=$ axillary bud, $\mathrm{p}=$ petiole of detached leaf. (B) Nodal explant 2 weeks in culture. Note the activation of the axillary bud and the growth at the basal end of explant. There is "swelling" of the stem in region surrounding axillary bud. (C) Nodal explant 4 weeks in culture. Note the activation of the axillary buds on the primary axillary bud and the presence of callus tissue eminating from the stem. (D) Nodal explant 6 weeks in culture sectioned through a region with extensive callus growth. It appears that an adventitious shoot (as) with an active axillary bud (ab) is present. Bars $=0.05$ $\mathrm{mm}$.

horizontally so that nodes were in contact with the medium. Shoot number and length were recorded after 12 weeks.

To observe the origin of shoots, permanent slides of histological sections were obtained using a standard dehydration series of ethanol and tert-butyl alcohol, paraffin embedding procedures, and safranin 0 and fast green staining solutions (Johansen, 1940). 
Rooting of microshoots (Expt. 5,). To evaluate the ex vitro rooting response of microshoots, a $2 \times 2$ factorial experiment consisting of all combinations of two soilless mixes and two container lids was initiated. Mixes consisted of either Redi Earth Peat-Lite Mix (W.R. Grace and Co., Cambridge, Mass.) or a steam-sterilized 1 peat : 1 sand mix. Rooting containers were Pro Tray 72 plug trays (plug volume $40 \mathrm{~cm}^{3}$ ) (Polyform, Plymouth, Minn.) covered with either a clear or a translucent Oasis Clean Start Lid (Smithers-Oasis, Kent, Ohio). Clear lids reduced the transmission of ambient light by $15 \%$; the translucent lid reduced it by $36 \%$. There were two whole tray replications per treatment. One microshoot $(\approx 1 \mathrm{~cm}$ tall with all leaves intact) was inserted per plug. Trays were placed in a shaded glassglazed greenhouse for 32 days with no fertilization. They were then uncovered and moved into an unshaded greenhouse where plantlets received $20 \mathrm{~N}-4.3 \mathrm{P}-16.6 \mathrm{~K}\left(12 \% \mathrm{NO}_{3}-\mathrm{N} ; 8 \% \mathrm{NH}_{4}-\mathrm{N}\right)$ twice a week for 28 days, at which time the number of rooted microshoots was recorded, shoots were harvested and dried in a forced-air oven, and weights recorded.

\section{Results and Discussion}

Shoot multiplication (Expt. 1). Growth regulators, cultivar, and subculture significantly affected shoot proliferation (Table 1 ). The greatest effect was caused by the addition of $2 \mathrm{iP}$ to the media. Shoot proliferation was extensive at 150 and $300 \mu \mathrm{M}$ 2iP (Table 2). In blueberry, considerably lower 2iP levels $(\approx 15$ to $75 \mu \mathrm{M}$ ) were optimal for inducing shoot proliferation (Chandler and Draper, 1986; Garley et al., 1979; Lyrene, 1980). Cranberry explants cultured on $2 \mathrm{iP}$-containing media formed a

Table 1. Significance of main effects and interactions between growth regulators, cultivars, and subculturing on the number of shoots produced in vitro from cranberry shoot-tip explants.

\begin{tabular}{|c|c|}
\hline $\begin{array}{l}\text { Main effects and } \\
\text { interactions }\end{array}$ & Significance \\
\hline $2 \mathrm{iP}$ & $\mathrm{LQ}^{* *^{\mathrm{z}}}$ \\
\hline IBA & NS \\
\hline $\mathrm{GA}_{3}(\mathrm{GA})$ & $* *$ \\
\hline Subculture (S) & $* *$ \\
\hline Cultivar (C) & $* *$ \\
\hline $2 \mathrm{iP} \times I B A$ & NS \\
\hline $2 \mathrm{iP} \times \mathrm{GA}$ & $* *$ \\
\hline $2 \mathrm{iP} \times \mathrm{S}$ & $* *$ \\
\hline $2 \mathrm{iP} \times \mathrm{C}$ & $*$ \\
\hline $\mathrm{IBA} \times \mathrm{GA}$ & NS \\
\hline $\mathrm{IBA} \times \mathrm{S}$ & NS \\
\hline $\mathrm{IBA} \times \mathrm{C}$ & NS \\
\hline $\mathrm{GA} \times \mathrm{S}$ & $* *$ \\
\hline $\mathrm{GA} \times \mathrm{C}$ & $* *$ \\
\hline$S \times C$ & NS \\
\hline $2 \mathrm{iP} \times \mathrm{IBA} \times$ & NS \\
\hline \multicolumn{2}{|l|}{ GA } \\
\hline $2 \mathrm{iP} \times \mathrm{IBA} \times \mathrm{S}$ & NS \\
\hline $2 \mathrm{iP} \times \mathrm{IBA} \times \mathrm{C}$ & NS \\
\hline $2 \mathrm{iP} \times \mathrm{GA} \times \mathrm{S}$ & $*$ \\
\hline $2 \mathrm{iP} \times \mathrm{GA} \times \mathrm{C}$ & NS \\
\hline $2 \mathrm{iP} \times \mathrm{S} \times \mathrm{C}$ & NS \\
\hline $\mathrm{IBA} \times \mathrm{GA} \times \mathrm{S}$ & NS \\
\hline $\mathrm{IBA} \times \mathrm{GA} \times \mathrm{C}$ & NS \\
\hline $\mathrm{IBA} \times \mathrm{S} \times \mathrm{C}$ & NS \\
\hline $\mathrm{GA} \times \mathrm{S} \times \mathrm{C}$ & $* *$ \\
\hline
\end{tabular}

${ }^{\mathrm{z}}$ The 2iP main effect was significant as both a linear (L) and quadratic (Q) function. There was no significant four-or five-way interaction. NS, $* * *$ Nonsignificant or significant at $P=0.05$ or 0.01 , retrospectivey.
Table 2. Number of cranberry shoots that proliferated in response to growth regulator type and concentration, subculture, and cultivar. Means are main effects across all treatments. ${ }^{\mathrm{z}}$

\begin{tabular}{lc}
\hline \hline Treatment & $\begin{array}{c}\text { Mean no. shoots/ } \\
\text { explant } \\
( \pm \mathrm{SE})\end{array}$ \\
\hline $2 \mathrm{PP}(\mu \mathrm{M})$ & $1.0 \pm 0.01$ \\
0 & $6.5 \pm 0.33$ \\
150 & $6.0 \pm 0.40$ \\
300 & \\
IBA $(\mu \mathrm{M})$ & $5.0 \pm 0.29$ \\
0 & $4.8 \pm 0.27$ \\
1 & \\
GA $(\mu \mathrm{M})$ & $6.3 \pm 0.32$ \\
0 & $3.5 \pm 0.21$ \\
1 & \\
Culture & $2.7 \pm 0.19$ \\
Initial & $5.1 \pm 0.32$ \\
First subculture & $7.2 \pm 0.45$ \\
Second subculture & \\
Cultivar & \\
Beckwith & $4.3 \pm 0.43$ \\
Bergman & $6.0 \pm 0.48$ \\
Franklin & $5.3 \pm 0.36$ \\
Stevens & $4.0 \pm 0.28$ \\
\hline
\end{tabular}

${ }^{\mathrm{z}}$ Original shoot is included in the values presented.

basal meristematic callus, and this callus was correlated with the production of many shoots. Axillary shoots were active only in the early stages of culture.

Across all treatments, IBA appeared to have no effect on the number of shoots produced (Tables 1 and 2). However, in treatments producing the maximum number of shoots in the initial culture stage, media containing IBA along with $2 \mathrm{iP}$ resulted in the production of 1.8 more shoots per explant than media without IBA (data not presented). Therefore, if all shoots had been subculture with each transfer, there would have been a substantial increase in shoot production on IBA-containing medium. Scorza et al. (1984) concluded that the addition of an auxin (indole-3-acetic acid) to $2 \mathrm{iP}$-containing media had a positive effect on cranberry shoot proliferation.

Unlike $2 \mathrm{iP}$ or IBA, $\mathrm{GA}_{3}$ significantly suppressed shoot proliferation (Tables 1 and 2) and did not improve shoot quality. Our reason for adding $\mathrm{GA}_{3}$ to the media was an attempt to elongate tiny basal shoots, since preliminary experiments indicated that most of the shoots near the basal region of the culture did not elongate and were difficult to subculture (data not presented). However, with $\mathrm{GA}_{3}$ included in the media, the cultures produced about half the number of shoots (Table 2). Since many of the shoots produced in our cultures may be of adventitious origin (Fig. 1D), and inhibition of adventitious shoot formation in vitro has been linked to gibberellins (Murashige, 1964; Nickell and Tulecke, 1959), de novo shoot formation may have been suppressed by $\mathrm{GA}_{3}$ addition.

Subculturing increased the number of shoots produced by shoot-tip explants. Under our optimal plant growth regulator regime and in the second subculture, 'Beckwith' and 'Bergman' cultures produced between 16 and 18 shoots per explant in 6 weeks. We do not know if the response was maximized after the second subculture, but cultures that had been subculture up to 10 times did not demonstrate noticeable increases in shoot production after the second subculture. Across all treatments, cultivars varied in their responses, with 'Bergman' being the most and 'Stevens' the least responsive (Fig. 2). There was a 


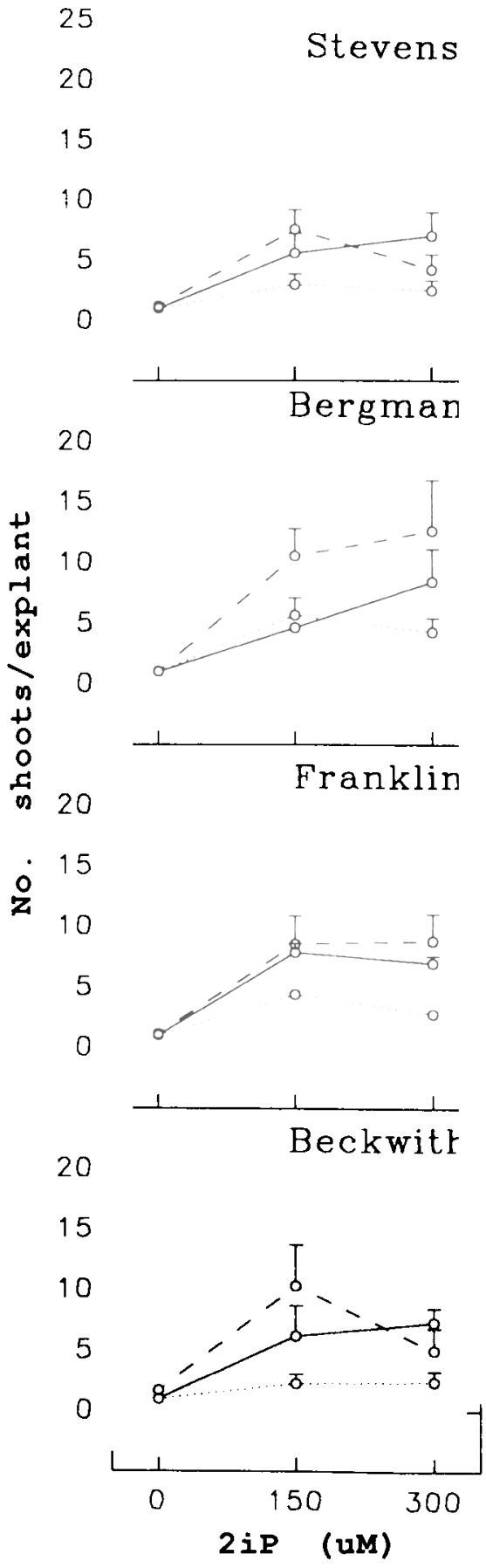

Fig. 2. The effect of $2 \mathrm{iP}$ level and subculture on the proliferation of shoots from shoot-tip explants of four cranberry cultivars. Dotted line $=$ initial culture; solid line $=$ first subculture; dashed line $=$ second subculture. Lower standard error bars omitted for clarity.

significant interaction between cultivar and 2iP level (Table 1, Fig. 2). Using highbush blueberries, Chandler and Draper (1986) also demonstrated cultivar variability in response to $2 \mathrm{iP}$ and to zeatin, with some clones producing twice as many shoots as others.

Evaluation of cytokinin levels (Expt. 2). Axillary buds were released from dormancy on hormone-free medium (Fig. 3). The 2iP level greatly influenced shoot production and the fraction of shoots that was of axillary origin (Figs. 3 and 4). Cultures composed entirely of axillary shoots were not produced unless the $2 \mathrm{iP}$ level was reduced to $5 \mu \mathrm{M}$, in which case shoot for-

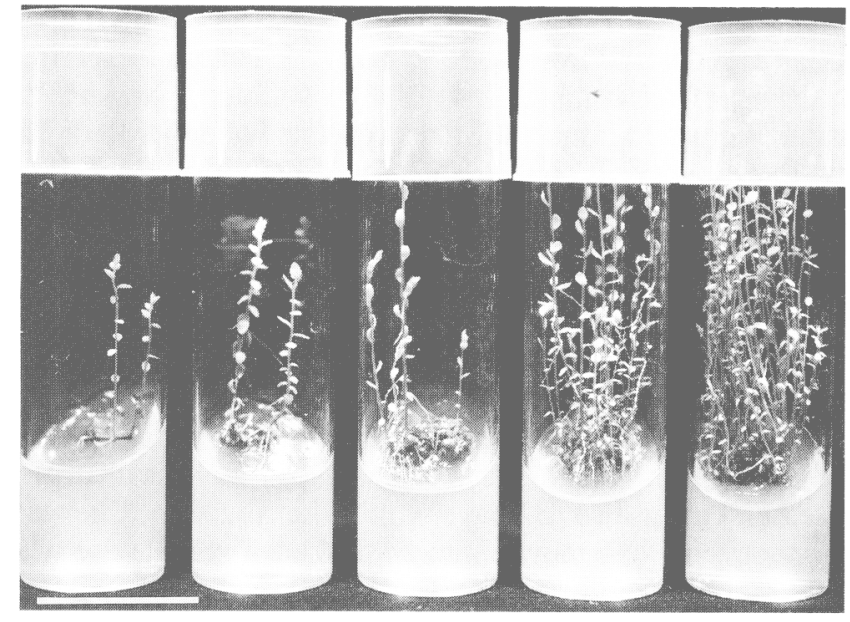

Fig. 3. Cranberry shoot cultures derived from two-node explants 7 weeks after culture was initiated. The $2 \mathrm{iP}$ levels (left to right) are $0,5,25,50$, and $150 \mu \mathrm{M}$. Note that at the lower concentrations of $2 \mathrm{iP}$, the two axillary buds become active, and at higher concentrations, a meristematic mass at the base of the culture gives rise to shoots that are apparently of both axillary and adventitious origin. Only occasionally did axillary buds located above the surface of the medium give rise to elongated shoots. White bar $=25 \mathrm{~mm}$.

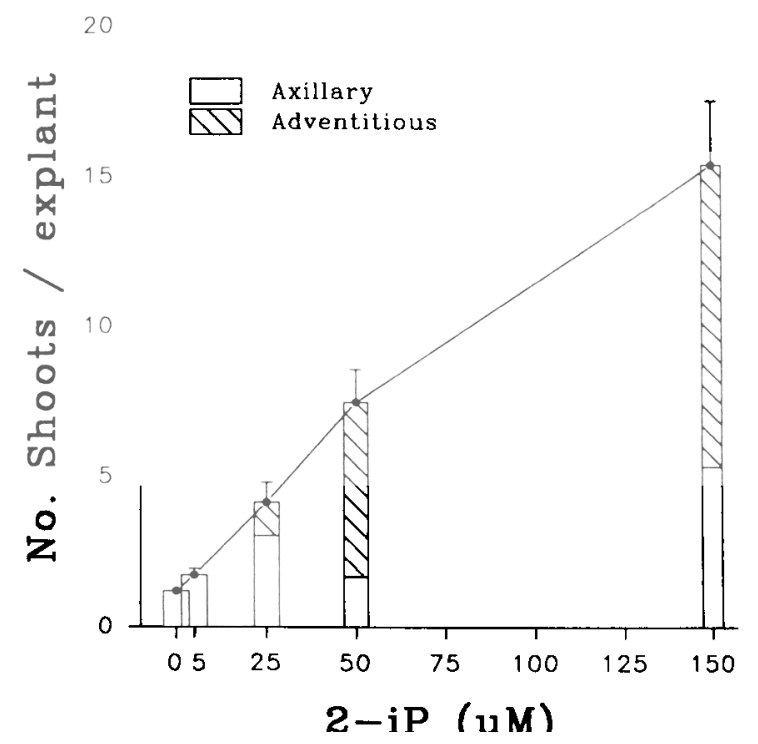

Fig. 4. Effect of $2 \mathrm{iP}$ level on shoot multiplication and the origin of shoots from two-node cranberry explants. Points represent means for the average of four cultivars. Lower standard error lines omitted for clarity. The bar below each point represents total shoot number and is subdivided to indicate the fraction of the total number that was of axillary or adventitious origin.

mation consisted on the release of axillary buds that preexisted on the explant. Aerial shoots displayed strong apical dominance, and sequential shoot formation was highly dependent on the basal mass of meristematic tissue.

Inorganic nutrition for shoot cultures (Expt. 3). Cultivar responses to the four commercially available salt formulations indicated that the use of a medium containing WPM salts presuited in more shoots than those containing either B-5 or Anderson's (Table 3). When MS salts were-used, shoots were short, many with compressed nodes and chlorotic leaves. With WPM salts, many shoots were purpose or yellow and variable in size. Wolfe et al. (1983) reported that WPM was superior to 
Table 3. Influence of salt formulation on shoot proliferation and height of cranberry shoot cultures. Means represent average of four cultivars and averages of an initial 12-week culture period and two 8week subcultures. ${ }^{\mathrm{z}}$

\begin{tabular}{|c|c|c|}
\hline Salt formulation & $\begin{array}{l}\text { No. shoots/ } \\
\text { explant }\end{array}$ & $\begin{array}{l}\text { Mean shoot } \\
\text { ht }(\mathrm{cm})\end{array}$ \\
\hline $\begin{array}{l}\text { Anderson } \\
\text { Gamborg (B-5) } \\
\text { Murashige and Skoog (MS) } \\
\text { Woodv Plant Medium (WPM) }\end{array}$ & $\begin{array}{l}6.2 \mathrm{~b} \\
6.5 \mathrm{~b} \\
8.5 \mathrm{ab} \\
10.5 \mathrm{a}\end{array}$ & $\begin{array}{l}1.4 \mathrm{a} \\
0.6 \mathrm{~b} \\
0.6 \mathrm{~b} \\
1.2 \mathrm{a}\end{array}$ \\
\hline \multicolumn{3}{|c|}{$\begin{array}{l}{ }^{2} \text { Mean separation within columns by Duncan's multiple range test, } P \\
=0.05 \text {. }\end{array}$} \\
\hline \multicolumn{3}{|c|}{$\begin{array}{l}\text { Table } 4 \text {. Effect of explant source on shoot proliferation of cranberry } \\
\text { cultures initiated on multiplication medium containing } 150 \mu \mathrm{M} 2 \mathrm{P} \\
\text { and } 1 \mu \mathrm{M} \text { IBA. Means are combined averages of 'Franklin' and } \\
\text { 'Bergman'. }\end{array}$} \\
\hline Criterion & & hoots/explant \\
\hline $\begin{array}{l}\text { Plant source (PS) } \\
\text { Greenhouse-grown } \\
\text { Microcultured shoot }\end{array}$ & & $\begin{array}{l}15.0 \\
14.8\end{array}$ \\
\hline $\begin{array}{l}\text { Tissue source (TS) } \\
\text { Shoot tip } \\
\text { Two node }\end{array}$ & & $\begin{array}{l}11.8 \\
18.2\end{array}$ \\
\hline $\begin{array}{l}\text { Main effects and interactions } \\
\text { PS } \\
\text { TS } \\
\text { PS } \times \text { TS }\end{array}$ & & $\begin{array}{l}\text { NS } \\
* \\
\text { NS }\end{array}$ \\
\hline
\end{tabular}

${ }^{\mathrm{NS}}, *$ Nonsignificant or significant at $P=0.05$, respectively.

modified MS medium and Zimmerman's medium (Zimmerman and Broome, 1980) for blueberry micropropagation, especially after the initial culture. However, in their study, WPM was not compared to Anderson's medium. In our study, shoots grown on Anderson's salts (1975) were uniform in size, greener, and more quickly rooted than those on WPM. Anderson's salts contain $200 \mu \mathrm{M} \mathrm{Fe} e^{+2}$ in contrast to the $100 \mu \mathrm{M}$ in WPM, MS, and B-5.

The essentiality of $\mathrm{NH}_{4}^{+}-\mathrm{N}$ in the nutrition of cranberry has been thoroughly documented (Greidanus et al., 1972). However, Anderson's and WPM salts have nearly identical molar concentrations and $\mathrm{NH}_{4}^{+}-\mathrm{N}: \mathrm{NO}_{3}^{-}-\mathrm{N}$ ratios; hence, growth differences of cultures grown on these two salt formulations cannot be explained by $\mathrm{N}$ nutrition. Suppression of growth on B-5 salts may be caused by the $\mathrm{NH}_{4}^{+}{ }_{4} \mathrm{~N}: \mathrm{NO}_{3}^{-}-\mathrm{N}$ ratio, which is 0.08 , in comparison to 0.5 for MS, WPM, and Anderson's.

Explant source (Expt. 4). The type of plant (i.e., greenhousegrown or microcultured) did not affect the number of shoots produced (Table 4). Therefore, using microculture shoots may be preferable for maintaining cultures since they do not require surface disinfestation once established. We do not know whether serial subculturing will lead to more phenotypic or genetic variation than when explants are taken periodically from greenhouse- or field-grown plants.

Although shoot-tip explants contained many more nodes than two-node explants, two-node explants produced more shoots (Table 4). In the nodal explants, axillary buds are fully developed (Fig. 1A), whereas shoot tips contain nodes without axillary buds or with immature axillary buds (not presented). Nodal explants formed a basal meristematic callus (Fig. 1D) more quickly; this event may explain the increased shoot production of these cultures.

When nodal explants were used, shoots became evident when dormant axillary buds became active (Fig. 1B). As the bud grew, the stem swelled and cell divisions were evident, especially at the basal cut end. With time, axillary buds of the primary axillary bud became active (Fig. 1C). Eventually, shoots elongated and a dense meristematic callus formed at the base of the culture. This callus gave rise to adventitious shoots (Fig. 1D). As the culture matured, most shoots arose from the basal regions and not from nodes of aerial shoots. We have pruned off and rooted shoots arising from meristematic callus and subculture sections of the callus. This pruning stimulates another series of shoots to arise from the basal callus (data not presented).

Rooting of microshoots (Expt. 5). Microshoots rooted in both Redi-Earth and the sand-peat mixture and under both lid types. There were no significantly different rooting responses between media types and no interactions between media and lid types. Therefore, media types were statistically treated as additional replications of lid types. Rooting percentages were $84.7 \% \pm$ $2.4 \%$ under translucent lids and $96.5 \% \pm 1.3 \%$ under clear lids. In addition, shoots rooted under clear lids accumulated nearly twice the dry weight (data not presented).

\section{Conclusions}

When compared to other systems, the two-stage micropropagation system described above reduces labor, decreases the probability of contamination, simplifies medium preparation, and lowers costs. If, however, somaclonal variation is apparent when the higher $2 \mathrm{iP}$ levels are used, this system may not become an economically feasible method for the large-scale commercial propagation of cranberries. Yet, when low levels of 2iP are used, micropropagation would still be useful for propagating elite germplasm. Field trials and phenotypic and genetic analysis will determine which of these possibilities will be feasible.

\section{Literature Cited}

Anderson, W.C. 1975. Propagation of rhododendrons by tissue culture. Part 1. Development of a culture medium for multiplication of shoots. Proc. Intl. Plant Prop. Soc. 25:129-135.

Billings, S. G., C.K. Chin, and G. Jelenkovic. 1988. Regeneration of blueberry plantlets from leaf segments. HortScience 23:763-766.

Callow, P., K. Haghighi, M. Giroux, and J. Hancock. 1989. In vitro shoot regeneration on leaf tissue from micropropagated highbush blueberry. HortScience 24:373-375.

Chandler, C.K. and A.D. Draper. 1986. Effect on zeatin and 2iP on shoot proliferation of three highbush blueberry clones in vitro. HortScience 21:1065-1066.

Eck, P. 1990. The American cranberry. Rutgers Univ. Press, New Brunswick, N.J.

Frett, J.J. and J.M. Smagula. 1982. In vitro shoot production of lowbush blueberry. Can. J. Plant Sci. 63:467-472.

Gamborg, O.L., R.A. Miller, and K. Ojima. 1968. Nutritional requirements of suspension cultures of soybean root cells. Expt. Cell Res. 50:151-158.

Garley, B., C. Stushnoff, D. Wildung, and P.E. Read. 1979. In vitro micropropagation of blueberry hybrids using single bud stem segments and stem tips. HortScience 14:477. (Abstr.)

Greidanus, T., L.A. Peterson, L.E. Schrader, and M.N. Dana. 1972. Essentiality of ammonium for cranberry nutrition. J. Amer. Sot. Hort. Sci. 97:272-277.

Johansen, D.A. 1940. Plant microtechnique. McGraw-Hill, New York. Lloyd, G. and B. McCown. 1980. Commercially-feasible micropropagation of mountain laurel, Kalmia latifolia by use of shoot-tip culture. Proc. Intl. Plant Prop. Sot. 30:421-427.

Lyrene, P.M. 1980. Micropropagation of rabbiteye blueberries. HortScience 15:80-81. 
Marcotrigiano, M., H.J. Swartz, S.E. Gray, D. Tokarcik, and J. Popenoe. 1984. The effect of benzylamino purine on the in vitro multiplication rate and subsequent field performance of tissue-cultured strawberry plants. Adv. Strawberry Prod. 3:23-25.

Murashige, T. 1964. Analysis of the inhibition of organ formation in tobacco tissue culture by gibberellin. Physiol. Plant. 17:635-647.

Murashige, T. 1974. Plant propagation through tissue culture. Annu. Rev. Plant Physiol. 25:135-166.

Murashige, T. and F. Skoog. 1962. A revised medium for rapid growth and bioassays with tobacco tissue cultures. Physiol. Plant. 15:473497.

Nickell, L.B. and W. Tulecke. 1959. Responses of plant tissue cultures to gibberellin. Bot. Gaz. 120:245-250.

Nickerson, N.L. 1978. In vitro shoot formation in lowbush blueberry seedling explants. HortScience 13:698.

Read, P.E., C.A. Hartley, J.G. Sandahl, and D.K. Wildung. 1987.
Field performance of in vitro propagated blueberries. Proc. Intl. Plant Prop. Soc. 37:450-452.

Scorza, R., W.V. Welker, and L.J. Dunn. 1984. The effects of glyphosate, auxin and cytokinin combinations on in vitro development of cranberry nodes. HortScience 19:66-68.

Serres, R.A., B.H. McCown, E. Zeldin, D.E. McCabe, and E.J. Stang. 1990. Applications of biotechnology to cranberry: A model for fruit improvement. XXIII Intl. Hort. Congr., Florence, Italy. p. 127. (Abstr.)

Wolfe, D. E., P. Eck, and C. Chin. 1983. Evaluation of seven media for micropropagation of highbush blueberry. HortScience 18:703705 .

Zimmerman, R.H. and O.C. Broom. 1980. Blueberry micropropagation, p. 44-47. In: R.H. Zimmerman (ed.). Proc. Conf. on Nursery Production of Fruit Plants through Tissue Culture: Applications and feasibility. USDA-SEA Agr. Publ. ARR-NE-11, Beltsville, Md. 